\title{
Moral hazard in marriage: the use of domestic labor as an incentive device
}

\author{
Selma Walther ${ }^{1}$
}

Received: 4 June 2015 / Accepted: 8 August 2016 / Published online: 28 September 2016

(C) The Author(s) 2016; This article is published with open access at Springerlink.com

\begin{abstract}
This paper argues that some women in developing countries use domestic labor as a tool to incentivize husbands. A theoretical model is derived based on the traditions of rural Malawi, where men often supplement farm income with wage labor. As wage labor is not observed by the wife, this creates moral hazard: husbands may not make enough effort to bring home wages. The model predicts that women overcome this by using domestic labor as an incentive device: they increase their domestic labor and reduce their leisure in response to good consumption outcomes, but only if they cannot rely on divorce threat as an alternative source of incentives. This prediction is confirmed using survey data from Malawi. Identification is based on the fact that Malawi's kinship traditions exogenously determine women's accessibility to divorce. Where divorce is not an option, women make inefficient labor choices in order to provide incentives.
\end{abstract}

Keywords Moral hazard $\cdot$ Divorce $\cdot$ Domestic labor $\cdot$ Matrilineal

JEL Classification $\quad \mathrm{D} 13 \cdot \mathrm{D} 82 \cdot \mathrm{J} 12 \cdot \mathrm{J} 22$

Electronic supplementary material The online version of this article (doi:10.1007/s11150-016-9347-8) contains supplementary material, which is available to authorized users.

Selma Walther

selma.walther@economics.ox.ac.uk

1 Nuffield College and Department of Economics, University of Oxford, Oxford, UK 


\section{Introduction}

In developing countries, women continue to specialize in domestic labor in households. This specialization has traditionally been considered a burden for women, primarily because it reduces their earnings power, which may reduce their power within marriage. However, women may use this specialization to their advantage, particularly when divorce is not a credible threat. The question I address in this paper is the following: do women use domestic labor as leverage to influence their husbands' actions in their favor, particularly when their outside options are low $?^{1}$ I structure a model of moral hazard in marriage based on the family institutions of Malawi, where exogenous kinship traditions imply that wives can divorce easily in some areas, but not others. Wives provide their husbands with incentives to invest effort in generating consumption. The model predicts that women with low outside options who cannot credibly threaten their husbands with divorce implement more stringent incentives through domestic labor than women who have high outside options and hence can credibly threaten with divorce. This prediction is confirmed in the data: where divorce is inaccessible, women make inefficient time allocation choices to generate incentives.

Becker's $(1973,1974)$ seminal contribution to our economic understanding of marriage rests on the idea that marriage takes place when there is a surplus to be gained for the two individuals, relative to staying single. Specialization within the household is an important driver of this surplus; this has traditionally involved women specializing in domestic production, and men specializing in market labor supply. However, this can lead to inefficiencies, if men cannot commit to compensating their wives for staying at home. For example, Cohen (1987) argues that marriage is a type of contract, with each spouse having expectations of a set of services that their partner will provide them with. At the same time, marriage is an incomplete contract; problems can arise when the inability to commit leads to inefficiently low investments, for example (Grossbard-Schechtman and Lemennicier 1999). A second problem arises because of the inherent lack of full information in marriage, as a result of which the effort spent generating marital goods, such as joint earnings, may be unobservable. This problem is exacerbated in developing countries, where women's low autonomy results in less influence within marriage. Divorce may be an empowering strategy that helps to overcome this problem (Cohen 1971; Reniers 2003). The threat of divorce forces husbands to involve their wives in decisions and to provide for them. However, divorce can be inaccessible to women, particularly if it makes them economically insecure or socially ostracized. If divorce is not a credible threat, a fundamental moral hazard problem in marriage remains.

I hypothesize that wives address this problem by using domestic labor as an incentive device. England and Folbre (2002) emphasize the role that marriage-specific resources, such as household work and affection, can play as sources of bargaining power if they can be credibly withheld. In cultures where men have official authority over women, women may hold "unassigned" power through the ability to withhold food and sexual services (Lamphere 1974, p. 99). Cohen's (1971) study of

\footnotetext{
${ }^{1}$ In this paper, I define an outside option to be the utility of a husband or wife if divorced.
} 
the patrilineal Kanuri in Bornu, for example, demonstrated that control of the household sphere was the main way in which women derived control in other spheres of marital life. The key to the effectiveness of this mechanism is specialization, which implies that a woman's labor cannot be easily replaced.

In this paper, I model the behavior of spouses in rural Malawi. Existing intrahousehold models are inadequate for capturing the potential for within-household sources of bargaining power. Bargaining and collective intra-household models (Manser and Brown 1980; Chiappori 1988) postulate that a woman's power within marriage is determined primarily by her outside option. Other models of the household have discussed within-marriage threat points (Lundberg and Pollak 1993) and the consequences of limited commitment on efficiency in marriage (Aura 2002; Lundberg and Pollak 2001; Rasul 2008). However, the use of incentives to generate desirable outcomes has not been addressed.

I propose a model in which wives use a combination of domestic labor and divorce threat to incentivize husbands because of a moral hazard problem. Wives observe the amount of income a husband brings home, which is a noisy signal of how much effort he has made to contribute to the household. They respond positively to a high amount and negatively otherwise. In order to test the model, I take advantage of the fact that kinship in Malawi, which is exogenously determined at birth, has a strong influence on divorce accessibility. This is because it determines the pattern of land inheritance that a household follows. As a result, the effect of divorce accessibility on behavior can be neatly compared through kinship.

In rural Malawi, there are two distinct kinship traditions. Most of Malawi is matrilineal: inheritance passes through the mother's line and matrilocality is common, where a married couple resides in the wife's natal village. The remainder of Malawi is patrilineal, where inheritance passes from father to son and patrilocality is common. Under matriliny, women's outside options are high because they own household land and have the support of their kin. ${ }^{2}$ As a result, divorce is a credible threat. In contrast, divorce is not a credible threat for patrilineal women who lose access to land on divorce. The model predicts that patrilineal women use domestic labor as a stronger incentive device than matrilineal women. The model is tested on wives' time use in Malawi: the results confirm the prediction.

The theoretical framework of this paper is related to the literature on asymmetric information, active incentives and domestic labor in marriage. Most of the current household economics literature focuses on Pareto efficient outcomes (Chiappori 1988; Lundberg and Pollak 1993), which are not supported by data on productive activities (Udry 1996). This motivates asymmetric information in marriage in this paper, which has already received some attention in the literature (Peters 1986; Friedberg and Stern 2014). Souza (2013) builds a moral hazard model of the family where the elderly provide the young with incentives to exert effort in the labor market, while Rasul (2008) demonstrates that bargaining over

\footnotetext{
${ }^{2}$ Although matriliny strictly implies that land passes from a brother to his sister's son (thus travelling through the lineage of the female, but never owned by her), in Malawi in practise matrilineal traditions have evolved so that women own land. Under patriliny, women rarely own land.
} 
fertility can lead to inefficient outcomes due to the inability of spouses to commit to future actions. Active incentives are modelled by Landes (1978), who explores the role of alimony as an enforcement mechanism for optimal marital investment. Domestic labor as a source of power is addressed by Pollak (2005) through its effect on the outside option rather than its use as a leverage device. This paper models and tests the existence of domestic labor as an incentive device to overcome asymmetric information in marriage. ${ }^{3}$

The use of domestic labor in the model is similar to the concept of "wife-services" in Grossbard (1976, p. 703), whereby in a society with extremely traditional gender roles, women provide domestic goods, and hence supply domestic labor, while men demand women's domestic labor, and compensate them for it. As in a standard labor supply model, the shadow wage is determined by the productivity of the wife, so that more able women will have a leftward shifted supply curve of domestic goods, because they demand a higher shadow wage than less able women. Interpreting the moral hazard model along the lines of Grossbard's model implies that women in Malawi supply domestic labor and are compensated by men with cash goods, such as clothing. In addition, productivity differences may affect the total amount of domestic labor supplied.

This paper offers important policy implications relating to female empowerment. Domestic specialization can be empowering for women, especially when their autonomy is otherwise low. However, using domestic labor as an incentive device prevents an efficient allocation of time. Accessible divorce is also empowering and may reduce the need for sources of power internal to marriage. Therefore, empowering women by making divorce more accessible can reduce inefficiencies in women's time allocation. One way of empowering women in developing countries is to grant them land rights.

The remainder of the paper is structured as follows. The next section presents some anthropological evidence on Malawi that is relevant to the paper. The theoretical model of marriage is presented in Section 3. Empirical tests are in Section 4 and Section 5 concludes.

\section{Life in rural Malawi}

\subsection{The agricultural year}

Around $90 \%$ of all employees in Malawi work in the agricultural sector (BignamiVan Assche et al. 2011). Most of these are involved in smallholder production with land plots under 3 hectares (Ellis et al. 2003). Due to the importance of agriculture for most of the Malawi population, labor is a key asset for household production (Phiri

\footnotetext{
3 There have been several empirical studies on female empowerment in developing countries (e.g., Anderson and Eswaran 2009); however, this is to the author's best knowledge the first paper to show empirically the use of domestic production as an active incentive device. Related to the present paper, Reniers (2003) shows that divorce can be an empowering strategy in Malawi while Alfano et al. (2011) observe that household-level sources of power are more important for women living in Indian states with low rather than high institutional female autonomy. This is a similar idea to this paper, as institutional autonomy encompasses divorce accessibility.
} 
1985). Most households combine farming, wage labor and small business to earn their livelihoods (Kerr 2005a).

The agricultural year in Malawi begins in October with the rainy season. The rainy season lasts from October until March, during which maize is grown as the primary subsistence crop (Takane 2008; Ellis et al. 2003). The dry season lasts from April until September. During the dry season, households consume the maize they have grown and engage in other, primarily non-agricultural, income-earning opportunities (Kerr 2005b).

\subsection{Division of labor and cash income}

The division of labor in Malawi is strongly regimented by culture and tradition. The primary use of households' labor is for subsistence production. ${ }^{4}$ The labor for the main crop, maize, is either shared or predominantly carried out by women (Spring 1995; Kerr 2005a; Hirschmann and Vaughan 1983). Short-term, off-farm labor opportunities are available throughout the year. Short-term work in the dry season usually involves tasks such as brick-making or vegetable gardening (Kerr 2005b). ${ }^{5}$ Men are responsible for generating this cash income for non-food necessities, such as clothing, salt and soap (Bignami-Van Assche et al. 2011). Women carry out a substantial amount of wage labor only when they are unmarried or their husbands do not contribute to the household. Spring (1995) also notes that households are becoming increasingly reliant on husbands bringing in income from outside opportunities.

The husband's cash-generating labor is off-farm and thus unobservable from the wife's perspective. Additional uncertainty arises because employers renegotiate agreed wages in the face of agricultural shocks (Takane 2008) or because wives do not know the earnings of the husband, giving husbands scope to conceal the true amount. In $42 \%$ of households studied by Kerr (2005a), wives did not know their husband's income. Often, husbands would not contribute their cash and would instead spend it on consumption goods such as alcohol, which was a growing problem in the region. There is a moral hazard problem: as husbands' cash-generating labor is unobservable to wives and husbands have to share their income, they have an incentive to under-invest effort from the perspective of the household.

Women are responsible for the domestic sphere of the household. Spring (1995) documents that women spend an equal number of hours on the farm and in domestic activities, finishing their domestic tasks before or after farm work. Activities include childcare, cooking, cleaning and fetching water and firewood. Men spend around two-thirds less time than their wives on domestic work; in addition, their domestic activity appears to primarily consist of house building and repair (Spring 1995).

\footnotetext{
4 The predominant crop grown is maize, although some households grow cassava and rice as food sources (Spring 1995). Good health is particularly important for the ability to carry out agricultural labor (Engberg et al. 1987).

5 These are not in conflict with own-farm agricultural production and are not normally an indicator of food insecurity. Instead, they are used to bring additional income to the household.
} 
Husbands have more leisure time than their wives, particularly in the dry season when off-farm income earning is not immediately necessary for the survival of the household (Kerr 2005a). Wives' domestic duties continue throughout the dry season, so that wives have to rise earlier than husbands to tend to domestic chores (Kerr 2005a). On the whole, Kerr (2005a) finds that most of the wives' tasks are yearround, whereas this is less the case for men. These observations suggest that during the dry season, husbands have the capacity to work more hours than they choose to. Indeed, wives in Kerr's (2005a) study frequently complained of low labor contributions of husbands towards the household. This suggests that husbands' cost of effort is high.

\subsection{Kinship traditions}

A crucial factor that affects intra-household behavior in Malawi is kinship, which is determined by the tribe a person is born into and is thus exogenous. Tribes are either patrilineal or matrilineal. ${ }^{6}$ The distinction is a function of many intricate rules that govern marriage, residence, custody over children and inheritance (Kerr 2005a). Traditionally, matrilineal systems of descent involve inheritance through the mother's side and the mother gains custody of children as well as land on divorce. Matrilocality is common, where the husband moves to the wife's village after marriage. Matrilocality implies that a husband is removed from his primary source of power: his kin (Reniers 2003). Should the couple divorce, the husband leaves the wife's village with nothing; local narratives say that the man should "leave with his blanket" (Reniers 2003, p. 180). Patrilineal systems are based on descent through the father's side and patrilocality is common, where the wife moves to the husband's village after marriage. Men keep land on divorce, so that patrilineal women who divorce are unable to earn a living without remarrying. ${ }^{7}$

Under patriliny, wives' outside options are low. As a result, the incentives to divorce are limited. The desperation of patrilineal wives in Malawi to assume any kind of control within marriage is well-documented by Kerr (2005a). The wives interviewed often claimed husbands were "harsh" (Kerr 2005a, p. 71) and not ready to share more of their cash income with the household. Although the cash income was inadequate, they felt that they had no power to change the situation. Excessive usage of alcohol was also observed in the community studied by Kerr (2005a), which affected the ability of husbands to provide labor and was a cost on scarce resources. Alcohol was the most frequently cited cause for marital conflict. The case of one husband is documented, whose wife stopped cooking for him due to his excessive drinking; this is an example of the type of incentives explored in this paper.

In contrast, women in matrilineal families have high outside options, as a result of which husbands are often more supportive. Safilios-Rothschild (1982) describes the

\footnotetext{
6 There are nine main ethnic divisions or tribes (Spring 1995). The matrilineal tribes are the Chewa, Nyanja, Mang'anja, Lomwe, Tonga and Yao. The patrilineal tribes include the Ngonde, Ngoni and Tumbuka. In addition, the less common Senga and Sena are patrilineal.

7 The rules of each kinship system are not always strictly upheld: matrilineal couples may end up settling down patrilocally and individuals may inherit land, regardless of kinship. Generally, however, patrilineal couples are more likely to marry patrilocally and the wife is less likely to inherit land from her natal kin, compared to matrilineal couples.
} 
strong kinship support offered to women in matrilineal communities, which leads to high female autonomy. Anthropologists acknowledge that marital ties are weaker in matrilineal societies (Peters 1997), potentially because the bond between a matrilineal sister and her brother is stronger and more loyal than the bond between the sister and her husband. Indeed, Walther (2016) shows that, on average, $12 \%$ of matrilineal households were headed by a divorced adult in 2011, in contrast to only $8 \%$ of patrilineal households. Matrilineal husbands need to work hard to avoid divorce: while the husband is seen by his wife's kin as a "work-horse," he may gain the respect of the family and community if he is hard-working (Phiri 1983, p. 260). Since divorced women lose any cash support from their husbands, they will only divorce if this support is inadequate.

\section{A model of moral hazard in rural households}

Consider a husband and wife who like to consume a private good that is bought with wages earned by the husband, and a public good which is the output of the wife's domestic labor. The husband decides how much effort to make at work. If he makes low effort, denoted $e=0$, he earns one unit of income with probability $q-\Delta$, and nothing otherwise. If he makes high effort, $e=1$, this probability increases to $q$, but he incurs a private utility cost $\psi$. The wife cannot observe effort directly, which generates a moral hazard problem. However, she can observe his income, which is a noisy signal of his effort.

The husband's income is split between husband and wife for the purposes of private consumption: if he earns one unit of income, he consumes $\alpha$ units and she consumes $1-\alpha$. In the baseline model, I assume for simplicity that this sharing rule is predetermined. In Section 3.3, I show that my main predictions are robust under reasonable conditions even when the sharing rule is endogenous.

Having observed income, the wife faces two choices. First, she decides whether to divorce her husband or stay married. ${ }^{8}$ Second, if still married, she chooses to exert effort $l \in[0,1]$ on domestic labor at a private utility cost $\gamma$ per unit. Domestic labor is a public good that provides utility $\lambda>\gamma$ per unit for each partner, which is proportional to the amount of domestic labor supplied. Let $\bar{u}^{h}$ and $\bar{u}^{w}$ denote the husband's and wife's utility in divorce.

For simplicity, I assume that preferences are linear and separable in private consumption, public goods and the cost of effort. Thus the husband's and wife's utility in marriage are

$$
\begin{gathered}
u^{h}=\alpha(q-\Delta(1-e))+\lambda l-\psi e \\
u^{w}=(1-\alpha)(q-\Delta(1-e))+\lambda l-\gamma l
\end{gathered}
$$

I focus on the case where $\Delta \alpha<\psi<\Delta$, which makes moral hazard salient: under this condition, it is efficient for the husband to make high effort, since this improves expected aggregate consumption, but he has a private incentive not to do so. Moreover, assume that $\lambda>\bar{u}^{h}$ and $\lambda-\gamma \geq \bar{u}^{w}$, so that, in principle, it is inefficient to

${ }^{8}$ I assume a no-fault divorce system. 
divorce because the benefits of sharing a public good exceed the couple's joint outside option.

As a benchmark, consider the first-best scenario where the husband's effort is verifiable. The couple can sign a binding contract, where the husband commits to making high effort. It is efficient in this case for the couple to stay married and for the wife to provide domestic labor $l=1$, independently of income. The resulting level of household welfare is

$$
W^{*}=q+2 \lambda-(\gamma+\psi)
$$

When effort is unobservable, it is no longer possible to write a contract which forces the husband to provide for the wife. The couple now faces a second-best problem. The husband cannot commit directly to make effort, and the only way in which he can be incentivized to do so is through her actions: the threat of divorce or of withholding domestic labor if the husband's income is low. I now consider optimal incentive contracts based on these threats in order to obtain empirical predictions.

Before deriving optimal contracts, it is useful to discuss two assumptions of the baseline model. First, I have assumed that the wife can observe the husband's income before making her divorce and labor supply decisions. If she cannot observe his income before making her decisions, then she cannot incentivize the husbands to make effort. However, incentive contracts can easily be recovered by recognizing that marriage is a repeated game. Suppose, for instance, that the timing is reversed but the game is repeated twice, at dates 0 and 1 . Then incentivze can be provided by divorcing or withholding domestic labor at date 1 if the husband's income at date 0 is low. The optimal contracting considerations below would be unchanged. In this sense, my predictions are robust to timing assumptions. Second, as is common in the moral hazard literature, I assume that the wife can commit to these threats. In Section 3.2, I argue that these threats are likely to be credible when there are repeated interactions.

To find the optimal incentive contract, note that there are three options: The wife can incentivize the husband by threatening to reduce domestic labor, by threatening to divorce, or she can decide not to incentivize him at all. Suppose first that the wife commits to reduce domestic labor to $l=1-x$ if the husband does not earn income. The husband will make effort as long as the incentive constraint $\Delta(\lambda x+\alpha) \geq \psi$ holds. Assume that $\Delta(\lambda+a) \geq \psi$, so that it is possible in principle to satisfy this constraint. The least distortive incentive contract is obtained when the incentive constraint just binds. The resulting household utility is

$$
\begin{aligned}
W_{\text {domestic }} & =W^{*}-(1-q)(2 \lambda-\gamma) x \\
& =W^{*}-(1-q) \frac{\psi-\alpha \Delta}{\Delta} * \frac{2 \lambda-\gamma}{\lambda}
\end{aligned}
$$

Welfare is lower than in the first-best case, because the wife withholds domestic labor whenever income is low, even if the husband has made effort. In other words, the incentive contract introduces a distortion by punishing the husband for bad luck when he earns low income. The surplus lost is $(1-q)(2 \lambda-\gamma) x$ : the probability of low wages times the lost surplus from $x$ units of domestic labor in this state.

Suppose now that the wife commits to divorce the husband with probability $d$ if he does not earn income. Then the husband will make effort as long as 
$\Delta\left[d\left(\lambda-\bar{u}^{h}\right)+\alpha\right] \geq \psi$. Again the least distortive contract sets $d$ just big enough to satisfy the incentive constraint, and the resulting household utlity is

$$
\begin{aligned}
W_{\text {divorce }} & =W^{*}-(1-q)\left(2 \lambda-\gamma-\bar{u}^{h}-\bar{u}^{w}\right) d \\
& =W^{*}-(1-q) \frac{\psi-\alpha \Delta}{\Delta} * \frac{2 \lambda-\gamma-\bar{u}^{h}-\bar{u}^{w}}{\lambda-\bar{u}^{h}}
\end{aligned}
$$

Welfare is still lower than in first-best, because divorce is inefficient. The surplus lost is again intuitive: low wages arise with probability $(1-q)$, and in this case the couple pays the deadweight cost of divorce $2 \lambda-\gamma-\left(\bar{u}^{h}+\bar{u}^{w}\right)$ with probability $d$.

Finally, suppose that the wife does not seek to incentivize the husband through domestic labor or divorce. Then he will make low effort and the resulting household utility is

$$
W_{0}=W^{*}-\Delta
$$

Let us focus on the case where the probability of earning wages $q$ is high enough, and where the cost of low effort $\Delta$ is high enough. In this case, it pays to incentivize the husband, since $W_{0}<\max \left\{W_{\text {domestic }}, W_{\text {divorce }}\right\}$. In particular, the optimal contract involves the withdrawal of domestic labor if and only if

$$
\frac{\bar{u}^{w}}{\bar{u}^{h}}<1-\frac{\gamma}{\lambda} \in(0,1)
$$

Domestic labor is a better incentive device than divorce, as long as the ratio of outside options $\bar{u}^{w} / \bar{u}^{h}$ is small. Intuitively, a low outside option $\bar{u}^{w}$ means that divorce is very disruptive for the wife, so that using domestic labor to provide incentives is preferable. Conversely, a high outside option $\bar{u}^{h}$ means that divorce is not a strong deterrent from the husband's perspective, again implying that domestic labor is a better way to provide incentives. Notice, in particular, that if wives are better off upon divorce than husbands $\left(\bar{u}^{w}>\bar{u}^{h}\right)$, then (1) cannot hold, and divorce will necessarily be the optimal incentive device.

\subsection{Empirical predictions}

The model above generates empirical predictions for the relationship between domestic labor, the private consumption of wives, and outside options. In particular, condition (1) suggests that the correlation between domestic labor and female private consumption is either zero or positive, and that this correlation will be more positive in samples where wives are relatively worse off after divorce, in the sense that their relative outside option $\bar{u}^{w} / \bar{u}^{h}$ is lower. ${ }^{9}$

The contribution of this paper is to test these predictions in the context of Malawi. I exploit the coexistence of matrilineal and patrilineal tribes in Malawi to obtain exogenous variation in the relative outside option $\bar{u}^{w} / \bar{u}^{h}$. Under patriliny, wives are relatively worse off after divorce because men tend to own most of the household

\footnotetext{
9 Female private consumption is a sub-category of household private consumption, and is the simplest way of seeing whether the woman has benefitted from the husband's labor supply. Household private consumption will depend on how much cash the husband has earned for himself, which may not be subject to the same theoretical or empirical predictions: it is not clear that the wife would reward or punish the husband for cash that he has earned for himself.
} 
land, which has two effects: on the one hand, patrilineal wives can bring fewer assets into a new marriage and thus find it harder to re-marry after divorce. They also lose access to land, and production associated with it, if they remain single. These factors imply that $\bar{u}^{w}$ is lower in patriliny. Section 4.5.3 examines attitudes to divorce by descent type and provides supporting evidence for this. On the other hand, husbands in patrilineal regions will find it easier to re-marry, and keep access to land if they remain single, so that $\bar{u}^{h}$ is higher in patriliny. Both effects work in the same direction: the wife's relative outside option is lower in patriliny, and it is, therefore, more likely that domestic labor will be used as an incentive device instead of divorce. This reasoning yields my central prediction:

Proposition 1 The correlation between wives' provision of domestic labor and their private consumption is positive and higher for patrilineal than for matrilineal households.

I can exploit two further pieces of information about outside options within kinship systems to obtain further predictions. First, patrilocal households are those residing in the husband's village of origin, which is likely to decrease the wife's relative outside option compared to matrilocal households. Second, the wife's relative outside option is higher when she has inherited some land from her family. These facts yield an additional prediction:

Proposition 2 Within kinship systems, the correlation between wives' provision of domestic labor and their private consumption is higher for patrilocal than matrilocal households, and lower for households where the wife has inherited land than other households.

In Section 4, I take these predictions to the data. In the remainder of this section, I discuss the robustness of the theoretical predictions when (i) the wife cannot commit to threats of divorce or low domestic labor, or (ii) the sharing rule for private consumption is endogenized, as well as the robustness to alternative mechanisms such as changes in cooperation or complementarities between domestic labor and consumption.

\subsection{Commitment}

If the wife cannot commit to incentive mechanisms, then there is a question of credibility: when divorce or withholding domestic labor is inefficient ex post, the wife might be tempted to renege on the incentive mechanism.

In reality, married couples interact repeatedly over time, and repeated interactions can alleviate concerns about credibility. One way of formalizing this notion is to assume that the wife wishes to maintain a reputation for being tough in the sense of Kreps and Wilson (1982). Suppose that the model above is repeated $N$ times and that the wife is one of two types: with probability $p$, she is tough and has an intrinsic desire not to cooperate with a husband who brings home low wages. With probability $1-p$, she is weak and her preferences are as in the baseline model.

A tough wife will punish the husband whenever he earns low wages, either by divorcing him if her outside option is high, or by withholding domestic labor if her outside option is low (thus the predictions above go through for strong wives by 
assumption). Kreps and Wilson (1982) show that if the time horizon $N$ is long, and if the future is not heavily discounted, then weak wives will also punish their husbands for earning low wages in equilibrium. This is because a wife who does not punish reveals herself to be weak, and loses the ability to incentivize her husband in all future periods.

A model of reputations is not the only way to generate commitment. One alternative is to think of marriage as an infinitely repeated game with imperfect information, as in Green and Porter (1984). Then, there could be an implicit agreement to withhold domestic labor for a few periods, or to end the marriage, if the husband earns low wages. These strategies will enforce high effort, with predictions similar to those in the static model, as long as discount factors are sufficiently high. Finally, one could think of marital contracts as a reference point in the sense of Hart and Moore (2008). In this setting, the reference point would be for the wife to expect to be provided with private consumption, giving her an incentive to 'shade' her performance on domestic labor if this expectation is not met.

In all of these cases, incentives are credible, even when wives are not committed to enforcing them. Thus, the predictions of Propositions 1 and 2 remain valid.

\subsection{Sharing rule}

In the baseline model, the husband always receives a share $\alpha$ of his income. If we drop the assumption that this sharing rule is fixed, a natural way to incentivize effort would be to give the husband more 'skin in the game' by increasing his share of private consumption to $\alpha^{\prime}>\alpha$ if his income is high. In particular, a higher share would give the husband the right incentives as long as $\Delta \alpha^{\prime} \geq \psi$.

This incentive mechanism can, in principle, be more efficient than distorting domestic labor supply or getting divorced. However, it requires that utility from private consumption is easily transferable from wife to husband; i.e. that the aggregate utility from private consumption does not fall substantially when a larger share is allocated to the husband. If moral hazard is a severe enough problem, this is unlikely to be the case. Suppose, for instance, that the wife has a subsistence level of private consumption $c_{0}$, below which her marginal utility of another unit of consumption is very high. Then if moral hazard is severe enough, such that $1-\psi / \Delta<c_{0}$, the husband can never be incentivized using the sharing rule without pushing the wife below her subsistence level, which is prohibitively costly. ${ }^{10}$ In this situation, the optimal incentive must involve either the withdrawal of domestic labor or divorce (possibly alongside a small change in the sharing rule). Thus, the qualitative predictions of Propositions 1 and 2 would be unchanged. ${ }^{11}$

\footnotetext{
${ }^{10}$ The example of subsistence utility is very stark, but the intuition generalizes easily. Suppose more generally that the utility derived from consumption is a concave function $u(c)$. The cost of allocating a larger share of private consumption to the husband is $-\frac{d}{d \alpha}[u(\alpha)+u(1-\alpha)]=\int_{1-\alpha}^{\alpha}\left|u^{\prime \prime}(c)\right| d c$. As long as the curvature of utility $\left|u^{\prime \prime}(c)\right|$ is sufficiently large, it will not be feasible to give the husband too big a share of his income without introducing considerable distortions.

11 A similar situation could occur if there is a high subsistence level of domestic labor. In this case, it would not be possible to simultaneously satisfy all constraints and meet the subsistence level, and so the domestic labor mechanism would not be implementable.
} 
Table 1 Sample characteristics by lineage

\begin{tabular}{|c|c|c|c|c|c|c|}
\hline & \multicolumn{2}{|c|}{ Matrilineal } & \multicolumn{2}{|c|}{ Patrilineal } & \multicolumn{2}{|c|}{$P$-values } \\
\hline & Women & Men & Women & Men & Wome & Men \\
\hline \multirow[t]{2}{*}{ Age (in 2004) } & 36.66 & 44.31 & 35.59 & 42.47 & 0.34 & 0.17 \\
\hline & $(0.72)$ & $(0.88)$ & $(0.85)$ & $(0.99)$ & & \\
\hline $\begin{array}{l}\text { Secondary } \\
\text { school educated } \\
(\%)\end{array}$ & 0.01 & 0.09 & 0.10 & 0.27 & 0.00 & 0.00 \\
\hline Rumphi (\%) & \multicolumn{2}{|c|}{0.01} & \multicolumn{2}{|c|}{0.83} & \multicolumn{2}{|c|}{0.00} \\
\hline Mchinji (\%) & \multicolumn{2}{|c|}{0.42} & \multicolumn{2}{|c|}{0.12} & \multicolumn{2}{|c|}{0.00} \\
\hline Balaka (\%) & \multicolumn{2}{|c|}{0.57} & \multicolumn{2}{|c|}{0.06} & \multicolumn{2}{|c|}{0.00} \\
\hline \multirow[t]{2}{*}{ Land (acres) } & 1.71 & 3.27 & 0.81 & 5.49 & 0.00 & 0.17 \\
\hline & $(0.18)$ & $(0.38)$ & $(0.13)$ & (1.56) & & \\
\hline Poor $(2004, \%)$ & \multicolumn{2}{|c|}{0.17} & \multicolumn{2}{|c|}{0.09} & \multicolumn{2}{|c|}{0.02} \\
\hline Poor (2006,\%) & \multicolumn{2}{|c|}{0.06} & \multicolumn{2}{|c|}{0.01} & \multicolumn{2}{|c|}{0.02} \\
\hline Patrilocal (\%) & \multicolumn{2}{|c|}{0.50} & \multicolumn{2}{|c|}{0.88} & \multicolumn{2}{|c|}{0.00} \\
\hline $\begin{array}{l}\text { Wife has land } \\
\text { inheritance }(\%)\end{array}$ & \multicolumn{2}{|c|}{0.61} & \multicolumn{2}{|c|}{0.14} & \multicolumn{2}{|c|}{0.00} \\
\hline \multirow{2}{*}{$\begin{array}{l}\text { Clothes ‘04 } \\
\text { ('000 MWK) }\end{array}$} & 0.31 & 0.91 & 0.73 & 1.13 & 0.00 & 0.62 \\
\hline & $(0.04)$ & $(0.39)$ & $(0.14)$ & $(0.20)$ & & \\
\hline \multirow{2}{*}{$\begin{array}{l}\text { Clothes ‘06 } \\
\text { ('000 MWK) }\end{array}$} & 0.80 & 1.15 & 0.79 & 1.07 & 0.92 & 0.67 \\
\hline & $(0.09)$ & $(0.11)$ & $(0.12)$ & $(0.15)$ & & \\
\hline$N$ & \multicolumn{2}{|c|}{200} & \multicolumn{2}{|c|}{138} & \multicolumn{2}{|c|}{338} \\
\hline
\end{tabular}

Standard errors in parentheses

$P$-values test whether patrilineal households are significantly different from matrilineal households

\subsection{Alternative mechanisms: complementarities and cooperation}

I now explore two alternative mechanisms, which might be expected to generate similar predictions to Propositions 1 and 2.

First, suppose that domestic labor and private consumption are complementary, so that the maginal utility from domestic labor is $\lambda$ if the husband's income is high, but only $\lambda_{0}<\lambda$ if it is low. The interesting case is when $2 \lambda_{0}<\gamma$, so that it is no longer efficient to provide domestic labor in case of low income. The first-best scenario is now (i) for the husband to make high effort, and (ii) for the wife to provide domestic labor if and only if he earns high income. The husband now has strong incentives to make effort, even in the absence of punishment: if he does not earn high income, the wife optimally stops providing domestic labor and the husband loses utility $\lambda$, on top of his loss of private consumption $\alpha$. Thus, he will make high effort voluntarily and the household is able to achieve the first-best outcome so long as $\Delta(\lambda+\alpha) \geq \psi$. (This is the same condition which I imposed above to ensure that domestic labor is a feasible incentive device.) In this case, moral hazard ceases to be a problem.

It follows that with complementarities, the correlation between private consumption and domestic labor can be positive, even if there is no moral hazard 
Table 2 Time use by gender and lineage

\begin{tabular}{|c|c|c|c|c|c|c|}
\hline & \multicolumn{2}{|c|}{ Matrilineal } & \multicolumn{2}{|c|}{ Patrilineal } & \multicolumn{2}{|l|}{$P$-values } \\
\hline & Women & Men & Women & Men & Women & Men \\
\hline \multicolumn{7}{|l|}{2004} \\
\hline Domestic & $\begin{array}{l}3.83 \\
(0.13)\end{array}$ & $\begin{array}{l}0.19 \\
(0.04)\end{array}$ & $\begin{array}{l}3.93 \\
(0.14)\end{array}$ & $\begin{array}{l}0.11 \\
(0.04)\end{array}$ & 0.58 & 0.21 \\
\hline Leisure & $\begin{array}{l}12.16 \\
(0.24)\end{array}$ & $\begin{array}{l}13.03 \\
(0.27)\end{array}$ & $\begin{array}{l}12.08 \\
(0.24)\end{array}$ & $\begin{array}{l}14.55 \\
(0.33)\end{array}$ & 0.80 & 0.00 \\
\hline Economic & $\begin{array}{l}2.46 \\
(0.21)\end{array}$ & $\begin{array}{l}6.59 \\
(0.31)\end{array}$ & $\begin{array}{l}1.99 \\
(0.23)\end{array}$ & $\begin{array}{l}4.62 \\
(0.35)\end{array}$ & 0.13 & 0.00 \\
\hline Cash labor & $\begin{array}{l}0.68 \\
(0.15)\end{array}$ & $\begin{array}{l}2.86 \\
(0.31)\end{array}$ & $\begin{array}{l}0.49 \\
(0.13)\end{array}$ & $\begin{array}{l}1.57 \\
(0.26)\end{array}$ & 0.38 & 0.00 \\
\hline Other & $\begin{array}{l}5.05 \\
(0.18)\end{array}$ & $\begin{array}{l}3.83 \\
(0.24)\end{array}$ & $\begin{array}{l}5.78 \\
(0.25)\end{array}$ & $\begin{array}{l}4.62 \\
(0.30)\end{array}$ & 0.02 & 0.04 \\
\hline \multicolumn{7}{|l|}{2006} \\
\hline Domestic & $\begin{array}{l}4.28 \\
(0.14)\end{array}$ & $\begin{array}{l}0.29 \\
(0.06)\end{array}$ & $\begin{array}{l}3.48 \\
(0.15)\end{array}$ & $\begin{array}{l}0.10 \\
(0.03)\end{array}$ & 0.00 & 0.01 \\
\hline Leisure & $\begin{array}{l}11.56 \\
(0.19)\end{array}$ & $\begin{array}{l}12.73 \\
(0.20)\end{array}$ & $\begin{array}{l}11.04 \\
(0.17)\end{array}$ & $\begin{array}{l}11.93 \\
(0.24)\end{array}$ & 0.04 & 0.01 \\
\hline Economic & $\begin{array}{l}2.67 \\
(0.21)\end{array}$ & $\begin{array}{l}6.04 \\
(0.27)\end{array}$ & $\begin{array}{l}3.88 \\
(0.29)\end{array}$ & $\begin{array}{l}6.54 \\
(0.34)\end{array}$ & 0.00 & 0.27 \\
\hline Cash labor & $\begin{array}{l}0.66 \\
(0.13)\end{array}$ & $\begin{array}{l}2.84 \\
(0.28)\end{array}$ & $\begin{array}{l}0.38 \\
(0.12)\end{array}$ & $\begin{array}{l}1.49 \\
(0.24)\end{array}$ & 0.13 & 0.00 \\
\hline Other & $\begin{array}{l}5.47 \\
(0.19)\end{array}$ & $\begin{array}{l}4.70 \\
(0.23)\end{array}$ & $\begin{array}{l}5.07 \\
(0.25)\end{array}$ & $\begin{array}{l}4.34 \\
(0.31)\end{array}$ & 0.19 & 0.35 \\
\hline$N$ & 20 & & 138 & & 338 & \\
\hline
\end{tabular}

Standard errors in parentheses. $P$-values test whether patrilineal households are significantly different from matrilineal households

problem. Thus, the first prediction of Proposition 1 can be generated by complementarities alone. However, this model does not yield the remaining predictions of Propositions 1 and 2. If there is no moral hazard problem, then outside options do not affect optimal choices, unless there are significant differences in household preferences - in particular, in the strength of complementarities-across kinship systems and between matrilocal and patrilocal households.

Second, suppose that in the baseline model, the wife's private cost of providing domestic labor exceeds her private benefit, $\gamma>\lambda$. If the husband's effort and the wife's labor supply were chosen as part of a non-cooperative game, then both of them would choose to shirk, setting $e=l=0$. By contrast, the cooperative outcome would be $e=l=1$, because both partners' activities generate spillovers to the other person. If we thought of the family as playing an infinitely repeated game, where deviations from the cooperative outcome are punished by reversion to noncooperation, we might expect to see the cooperative outcome in young households, 
followed by occasional breakdowns in cooperation. This mechanism would generate a positive correlation between domestic labor and private consumption. In order to generate the additional predictions of Propositions 1 and 2, however, it would be necessary to argue that changes between cooperation and non-cooperation are less likely in matrilineal households, so that on average, the correlation between domestic labor and consumption is lower for this group. This implies that matrilineal households are mostly cooperative, or mostly uncooperative, whereas patrilineal households often transition between the two. The key point is that this necessarily also implies that both domestic labor and cash income are on average either higher or lower among matrilineal than patrilineal households, which Tables 1 and 2 show is not the case. Thus, differences in cooperation are unable to simultaneously generate the predictions in Propositions 1 and 2 and to explain the empirical results.

\section{Empirical analysis}

\subsection{Identification}

To test Proposition 1, I use a first-difference analysis to examine the effect of a change in consumption on the change in wife's domestic labor supply. This overcomes the problem that the particular levels of labor supply in a household cannot be identified as high or low. It also avoids the issue of constant omitted variables that affect labor supply. ${ }^{12}$ To differentiate between whether or not the divorce threat mechanism is in use, I rely on the fact that kinship is an exogenous determinant of outside options in Malawi. Matrilineal women have high outside options, while patrilineal women have low outside options. The difference between these outside options is assumed to be large enough such that the ratio in equation (1) holds on average for patrilineal women but not matrilineal women. As a result, I expect to observe more stringent domestic labor incentives by patrilineal women than matrilineal women. ${ }^{13}$

I assume that labor supply is a linear function of its determinants and formulate a first-difference regression equation. I estimate the equation with a full set of interaction dummy variables for kinship, which effectively means that the equation is estimated separately for patrilineal and matrilineal households. Letting $M$ be a dummy variable equal to 1 if the household is matrilineal and zero

\footnotetext{
12 One such variable is bargaining power, which is likely to affect both consumption and labor supply. Bargaining power is unlikely to vary across time in rural Malawi because it is primarily a function of land ownership, which is determined at marriage. Land purchases are rare and most land changes hands through inheritance. An alternative source of bargaining power, savings, are minimal in rural Malawi (see Walther 2016).

13 Variation in kinship may not only reflect variation in outside options, but also variation in other factors that affect consumption and domestic labor, such as effort or productivity. However, in the present sample there are eight tribes, four of which are matrilineal. Therefore, any characteristic that varies with kinship must hold for all four tribes: for example, that four of the tribes are simultaneously harder working than the other four and also matrilineal. This characteristic also needs to cause consumption and domestic labor to increase together. This is unlikely and I assume that it is not the case here.
} 
otherwise, I estimate

$$
\Delta l_{i}=\alpha+\alpha_{M} M_{i}+\beta \Delta C_{i}+\beta_{M} M^{*} \Delta C_{i}+\theta \Delta \mathbf{X}_{i}+\theta_{M} M^{*} \Delta \mathbf{X}_{i}+\Delta \varepsilon_{i}
$$

where there are $i=1, \ldots, N$ households, $\mathbf{X}_{i}$ is a vector of control variables, $\Delta l_{i}=l_{i, t}$ $-l_{i, t-1}, \Delta C_{i}=C_{i, t}-C_{i, t-1}, C_{i, t}$ is the wife's private consumption level in period $t$, $\Delta \mathbf{X}_{i}=\mathbf{X}_{i, t}-\mathbf{X}_{i, t-1}$ and $\Delta \varepsilon_{i}=\varepsilon_{t}-\varepsilon_{t-1} \cdot{ }^{14}$ The model predicts the following:

$$
\begin{gathered}
\beta>0 \\
\beta+\beta_{M}<\beta
\end{gathered}
$$

The first inequality implies that patrilineal wives respond positively with their domestic labor to increased consumption. The second inequality implies that this response is smaller for matrilineal wives than patrilineal wives.

To measure outside options more accurately, I also take into account marital residence. Patrilocal women have lower outside options than matrilocal women, so that a particularly strong response should be observed for patrilineal-patrilocal women and a particularly weak response for matrilineal-matrilocal women.

To measure the wife's domestic labor, I use the number of hours the wife spent on domestic activities (cooking, cleaning and doing laundry) during the previous regular working day. For the wife's private consumption, I use the amount of money spent on the wife's clothing, fabric for clothing and shoes in the past three months. The possible reverse causality between labor and spending is addressed by the fact that the reported spending covers a period of time prior to the time diary, namely the preceding three months. Further, labor supply in itself is easier to adjust than spending, because spending requires first an adjustment of labor supply in order to earn the required income for additional spending (or a reduction in labor supply leading to reduced income and thus spending). Therefore, it is conceivable that spending in the last three months reflects husbands' efforts to earn cash one to four months ago. This alleviates concerns about reverse causality.

The control variables in $\mathbf{X}$ are spending on husband's clothing, fabric for clothing and shoes in the past three months, land assets (to control for outside options), the average clothes spending of wives in the village (to control for income-earning opportunities), the health status of the spouses, a dummy variable indicating whether the interviewer perceives the house to be poor, household size and the total number of hours accounted for by the wife in her time diary. Further details of all variables are given in Appendix A.

In order to properly identify the divorce threat mechanism, one would need to examine those couples who divorce in matrilineal marriages. Divorce should be negatively correlated with consumption. However, the data does not allow this test because most of the couples who divorce leave the sample and this cause of attrition is not distinguished from migration or death. As a result, I interpret the matrilineal marriage as the baseline scenario, with the patrilineal marriage a special case of that, namely when divorce is not accessible.

There may be plausible alternative stories that explain the results. In addition to the theoretical analysis of alternative mechanisms in Section 3, I carry out several

\footnotetext{
${ }^{14}$ Most of the married couples in the sample are of the same lineage. A small proportion are mixed lineage; for those, I use the lineage of the wife.
} 
robustness checks empirically: I examine the impact of clothes spending on leisure and other time use categories in the main results and I take into account land inheritance, district- and district-descent-specific labor shocks and heterogeneity of responses. I also examine respondents' viewpoints on divorce to provide further evidence on the difference in outside options across kinship types, as well as analysing respondents' attitudes to domestic violence to show that husbands cannot counteract low domestic labor with violence.

\subsection{Data}

The data comes from the Malawi Longitudinal Study of Families and Health, conducted by the University of Pennsylvania in partnership with the College of Medicine and Kamuzu College of Nursing in Malawi. Although not constructed to represent the national population, characteristics of the sample are close to those observed in the rural sample of the Malawi Demographic and Health Survey. A roughly equal number of people were interviewed in the three districts of Rumphi (North), Balaka (South) and Mchinji (Centre). The sample consists of ever-married women between the ages of 15-49 in each district and their husbands. I use the 2004 and 2006 survey waves. ${ }^{15}$ After restricting the sample to those households interviewed in both years and those that satisfy some basic criteria, the final sample consists of 338 households. ${ }^{16}$ Time use data was collected using a time diary with half-hour intervals, where individuals selected one out of 40 possible activities. Spending on clothing is measured based on the answer to the question: "In the past 3 months, approximately how much did you spend in total on clothes, fabric for clothes or shoes for yourself?" As three months is a relatively long recall period, we might expect random measurement error in the answers to this question. In this case, the coefficient on women's clothing could suffer from attenuation bias, so that the true effect is larger than what is found in the empirical results.

Two potential sources of sample bias are addressed: general attrition and the exclusion of those couples who divorce between 2004-2006 but remain in the sample. Sample attrition between the two waves does not exhibit strong patterns. When comparing those who leave the sample after 2004 with those who do not, few differences in basic characteristics are found. Those who remain in the sample but report being divorced, separated or having a new spouse are small in number but similar on basic characteristics. Men who divorce or remarry tend to be poorer. Divorce or remarriage is more likely in matrilineal settings, which is consistent with the hypothesis that matrilineal women use divorce threat more than patrilineal women. In addition, clothes spending is lower on average in 2004 for those who divorced or remarried after. Thus, poor consumption outcomes are correlated with higher divorce rates, which is also consistent with the theoretical framework.

\footnotetext{
$\overline{15}$ The data used in the study are for the 2003-2004 and 2005-2006 agricultural seasons, with interviews taking place during the dry season. Agricultural production in these two seasons was normal (Takane 2008; Denning et al. 2009).

${ }^{16}$ I exclude polygamous households, households where the husband is ordinarily resident elsewhere and households where the months of the interviews in 2004 and 2006 were more than two months apart. This is to avoid confounding factors relating to labor patterns across the agricultural year.
} 


\subsection{Summary statistics}

Some characteristics of the sample are shown in Table 1. I focus on differences across lineage, as this is an exogenous variable. In terms of basic characteristics, education is higher in patrilineal marriages, both for wife and husband. This is because the patrilineal North has a more developed education system, the legacy of religious missionaries in colonial times (Reniers 2003). The regional differences are obvious; while $57 \%$ of matrilineal marriages are in Balaka, only $1 \%$ are in Rumphi. Both the amount of land owned and whether a woman has inherited land support the key premise for identifying the mechanism, which is that matrilineal women have significantly better outside options than patrilineal women.

Patrilocality and inheritance are strongly correlated with lineage. While $88 \%$ of all patrilineal marriages in the sample are patrilocal, only $50 \%$ of matrilineal marriages are. This suggests that matrilineal couples have some flexibility in location upon marriage, whereas patrilineal couples do not. Similarly, $61 \%$ of matrilineal women have inherited land, in contrast to $14 \%$ of patrilineal women.

Next, I examine the division of labor (Table 2). ${ }^{17}$ There is strong evidence that women hold a monopoly over domestic labor. They spend around four hours on domestic work on average per day, while their husbands spend less than half an hour on average. Men tend to spend more time on economic labor than their wives. In particular, they spend significantly more time on cash labor than their wives, on average. These observations are consistent with the division of labor described in Section 3. The average hours of domestic labor increase for matrilineal women between 2004 to 2006, so that in 2006, matrilineal women spend significantly more time on domestic labor than patrilineal women. One might be concerned if patrilineal women's domestic labor increased between the two periods, along with an increase in their average spending on consumption goods. This could lead to spurious correlation. However, since we are expecting matrilineal wives to use weaker incentives than patrilineal wives, this increase in average domestic labor is unlikely to explain the regression results. The increase is likely driven by an unobservable shock, and I control for district-specific and district-descent-specific shocks in the robustness checks. Further, I control for any changes in the average values of labor supply in the regressions by including a dummy variable for being matrilineal, as well as the difference in the total hours reported in the diary between the two periods. ${ }^{18}$

\subsection{Regression results}

In order to test Proposition 1, I estimate equation (2) by regressing the change in domestic labor from 2004 to 2006 on the change in wives' clothes spending, with a full set of interaction dummies for kinship. Table 3 shows the value of the coefficients of interest for the first set of regressions. Full results are in the Online Appendix.

\footnotetext{
17 See Appendix A for the activities included in each category.

18 The summary statistics also show that there is a large enough range in hours of domestic labor for it to be a reliable incentive device. In 2004, wives' domestic labor ranged from 0 to 10.5 hours per day. In 2006, it ranged from 0 to 11 hours per day.
} 
Table 3 The effect of consumption on labor by lineage

\begin{tabular}{llllll}
\hline$\Delta$ Consumption & (1) $\Delta$ Dom & (2) $\Delta$ Leis & (3) $\Delta \mathrm{D}-\Delta \mathrm{L}$ & (4) $\Delta \mathrm{D}+\Delta \mathrm{L}$ & (5) $\Delta$ Econ \\
\hline Patrilineal $(\hat{\beta})$ & $0.159^{* *}$ & $-0.292^{* *}$ & $0.451^{* * *}$ & -0.134 & -0.162 \\
Matrilineal $\left(\hat{\beta}+\hat{\beta}_{M}\right)$ & $0.053^{*}$ & $-0.004^{*}$ & $0.058^{* *}$ & 0.049 & 0.081 \\
$N$ & 338 & 338 & 338 & 338 & 338 \\
$R^{2}$ & 0.136 & 0.148 & 0.134 & 0.160 & 0.085 \\
\hline
\end{tabular}

Value of $\hat{\beta}_{M}$ in regression (1): $-0.105(P$-value 0.495$)$

${ }^{* * *}$ Denotes significance at $1 \%$ level, ${ }^{* *}$ at $5 \%$ level and * at $10 \%$ level. For the sum of two coefficients, significance corresponds to an F-test on the joint significance of all coefficients

Regression (1) shows that an additional 1000 MWK ( £1.60) spent on patrilineal wives' clothing in the last three months results in about ten more minutes of housework per day. ${ }^{19}$ Matrilineal wives have a weaker response: their marginal increase per $1000 \mathrm{MWK}$ is only three min. This supports Proposition 1. I also report the estimated value of $\beta_{M}$, which the model predicts should be negative. This is indeed the case, although the coefficient is not statistically significant at conventional levels. One possible alternative explanation of the results is that greater clothes spending is correlated with being better off, which results in a reduced need for farm labor and thus an increase in domestic labor. However, regressions (2) and (3) show that there is a clear substitution for both kinship types from leisure into domestic labor: leisure falls significantly for patrilineal wives and the difference in labor supply changes in (3) is highly significant. On the other hand, the sum of the differences in (4) is not significant for either kinship type, which shows that there is a substitution between domestic labor and leisure. ${ }^{20}$ Regression (5) demonstrates that there is no effect on economic labor for patrilineal or matrilineal households. This supports the idea that the observed change in domestic labor is an active incentive device, rather than an income effect.

Next, I test Proposition 2 by dividing the households further by marital residence, as this is likely to have a strong impact on a woman's outside option. In particular, patrilineal-patrilocal women have the lowest outside options, so that condition (1) is most likely to be satisfied, while matrilineal-matrilocal have the highest outside options, so that this condition is least likely to be satisfied. Regressions (6)-(10) in Table 4 demonstrate these results. Patrilineal-matrilocal marriages are rare in Malawi; in the present sample there are only 17 households of this type, so I leave the result for this group to the Online Appendix. The hypothesis that women with low outside options respond more strongly to changes in consumption than women with high outside options is supported here: while patrilineal-patrilocal women increase their domestic labor by a highly significant 12 min per day in response to a $1000 \mathrm{MWK}$ increases in

\footnotetext{
19 The summary statistics show that clothes spending is $\sim 1000 \mathrm{MWK}$ on average. Therefore, an increase by this amount represents a doubling of clothes spending.

20 This substitution effect also counters the idea that we are observing increasing returns to specialization - the more domestic labor a woman does, the higher the efficient level of her domestic labor (and similarly for income generation for the husband). In this case, the wife would substitute out of economic labor into domestic labor and not out of leisure.
} 
Table 4 The effect of consumption on labor by lineage and residence

\begin{tabular}{llcccc}
\hline$\Delta$ Consumption & $(6) \Delta \mathrm{Dom}$ & $(7) \Delta \mathrm{Leis}$ & $(8) \Delta \mathrm{D}-\Delta \mathrm{L}$ & (9) $\Delta \mathrm{D}+\Delta \mathrm{L}$ & $(10) \Delta \mathrm{Econ}$ \\
\hline Plin-Patrilocal $(N=120)$ & $0.195^{* * *}$ & $-0.288^{* *}$ & $0.483^{* * * *}$ & -0.092 & -0.200 \\
Mlin-Patrilocal $(N=99)$ & $0.090^{* *}$ & $0.185^{*}$ & $-0.095^{* *}$ & 0.276 & -0.314 \\
Mlin-Matrilocal $(N=101)$ & $0.007^{* * *}$ & $-0.345^{*}$ & $0.352^{*}$ & $-0.338^{* *}$ & $0.617^{* * *}$ \\
$N$ & 337 & 337 & 337 & 337 & 337 \\
$R^{2}$ & 0.147 & 0.168 & 0.148 & 0.185 & 0.100 \\
\hline
\end{tabular}

Value of $\hat{\beta}_{M}$ (Mlin-Mloc) in regression (6): -0.189 ( $P$-value 0.019$)$

"Plin" stands for Patrilineal, "Mlin" stands for Matrilineal and "Mloc" stands for Matrilocal

*** Denotes significance at $1 \%$ level, ${ }^{* *}$ at $5 \%$ level and ${ }^{*}$ at $10 \%$ level. For the sum of two or more coefficients, significance corresponds to an F-test on the joint significance of all coefficients

clothes spending, the response of matrilineal-matrilocal women is negligible. The value of $\hat{\beta}_{M}$ for the matrilineal-matrilocal group supports Proposition 1: it is negative and significant, with a $P$-value less than $5 \%$. This suggests that this particular group responds more weakly to increases in consumption than the patrilineal-patrilocal group. The response of matrilineal-patrilocal woman is inbetween these two, which is consistent with the idea that their outside options are intermediate.

Regression (7) demonstrates that leisure falls significantly for patrilineal-patrilocal and matrilineal-matrilocal wives. In particular, the absolute value of the coefficient for patrilineal-patrilocal wives is similar in regressions (6) and (7), showing a substitution effect. This is confirmed in regression (8), which shows that the difference between domestic labor and leisure increases by $30 \mathrm{~min}$ for patrilineal-patrilocal wives. Regression (9) confirms that this is a substitution effect, as the sum of the two differences is not significant. The clearest effect of consumption on a substitution from leisure into domestic labor is seen for patrilineal-patrilocal wives, who are the least empowered group in Table 4. There is no effect on economic labor for patrilineal-patrilocal wives; in contrast, matrilineal-matrilocal wives exhibit a strong positive response of economic labor to spending, suggesting that they may be playing a role in earning cash.

These results confirm that first, the domestic production mechanism exists, and second, that there is more reliance on it in marriages where wives have low outside options. The latter hypothesis is confirmed in an apparent way, with highly significant and positive coefficients on spending for marriages where women have low outside options and coefficients close to zero where women have high outside options. Taking into account marital residence demonstrates that being surrounded by kin is a crucial factor that increases a woman's outside option in Malawi.

The results signify some important conclusions. Matriliny and its implications for land rights and marital residence are sources of empowerment for women. They do not have to rely on inefficient sources of power within marriage, such as domestic labor, to encourage their husbands to work hard. In contrast, women with low outside options are not able to divorce if their husbands do not provide cash income. Instead, they are left with little leverage aside from their role in the domestic sphere. Making divorce easy and fair is a key pathway towards improving female autonomy. A particularly potent way of achieving this is by granting land rights to women. 
Table 5 The effect of consumption on labor by lineage and land inheritance

\begin{tabular}{llllll}
\hline$\Delta$ Consumption & (I) $\Delta$ Dom & (II) $\Delta$ Leis & (III) $\Delta \mathrm{D}-\Delta \mathrm{L}$ & (IV) $\Delta \mathrm{D}+\Delta \mathrm{L}$ & (V) $\Delta$ Econ \\
\hline Plin-NO land $(N=118)$ & $0.209^{* * * *}$ & $-0.286^{* *}$ & $0.495^{* * *}$ & -0.076 & -0.214 \\
Mlin-No land $(N=77)$ & $0.104^{* * *}$ & -0.085 & $0.189^{* *}$ & 0.020 & -0.233 \\
Mlin-Land $(N=123)$ & $0.024^{* * *}$ & 0.037 & -0.013 & 0.061 & 0.297 \\
$N$ & 338 & 338 & 338 & 338 & 338 \\
$R^{2}$ & 0.145 & 0.155 & 0.144 & 0.166 & 0.093 \\
\hline
\end{tabular}

Value of $\hat{\beta}_{M}$ (Mlin-Land) in regression (I): -0.186 ( $P$-value 0.329)

"Plin" stands for Patrilineal, "Mlin" stands for Matrilineal

*** Denotes significance at $1 \%$ level, ${ }^{* *}$ at $5 \%$ level and * at $10 \%$ level. For the sum of two or more coefficients, significance corresponds to an F-test on the joint significance of all coefficients

\subsection{Robustness checks}

In order to verify the robustness of the empirical results, I examine land inheritance instead of descent, allow for heterogeneous responses by various characteristics, allow for district-specific and district-descent-specific shocks to labor as well as examine attitudes to divorce and domestic violence.

\subsubsection{Land inheritance}

Land inheritance is arguably a more important determinant of outside options than descent, as it more accurately captures whether a spouse can survive economically on divorce. Thus, I interact descent with whether the wife owns land or not to provide a more accurate measure of outside options, which is also a test of Proposition 2. Table 5 orders marriages in terms of accessibility of divorce, with divorce being least accessible for patrilineal-no land wives and most accessible to matrilineal-land wives. The results confirm that the extent to which women increase their domestic labor in response to spending is correlated with the accessibility of divorce. Regression (I) demonstrates a highly significant, positive response of domestic labor to spending for patrilineal-no land wives, who work an additional $12 \mathrm{~min}$ per day in the home when they receive an additional $1000 \mathrm{MWK}$ of clothes spending. This is larger than the effect for all patrilineal wives in regression (1), suggesting that no land inheritance makes divorce even less accessible. The effect for matrilineal-no land wives is positive and significant but smaller, which is consistent with the idea that divorce is more accessible to women in this type of marriage. The effect for matrilineal-land wives is close to zero, which is again in line with the predictions of the theoretical framework. This is supported by the value of the coefficient on $\hat{\beta}_{M}$, which is negative, although not significant at conventional levels. ${ }^{21}$

The robustness of these results for patrilineal-no land wives is confirmed in regressions (II)-(V). There is a clear substitution from leisure into domestic labor for patrilineal-no land wives. While leisure falls by nearly $20 \mathrm{~min}$ per day, the difference

\footnotetext{
${ }^{21}$ As with marital residence, I omit the result for the Patrilineal-Land group in this table, of which there are only 20 households in the sample. The result is in the Online Appendix.
} 
Table 6 Heterogeneous responses and district-specific shocks

\begin{tabular}{llllll}
\hline$\Delta$ Consumption & $\begin{array}{l}\text { (a) }+\Delta \text { Land } \\
* \Delta \text { Dom }\end{array}$ & $\begin{array}{l}\text { (b) }+\Delta \text { Poor } \\
* \Delta \text { Dom }\end{array}$ & $\begin{array}{l}\text { (c) }+\Delta \text { Children } \\
* \Delta \text { Dom }\end{array}$ & $\begin{array}{l}\text { (d) +District } \\
\text { (e) }+ \text { District } \\
* \text { matrilineal }\end{array}$ \\
\hline Patrilineal $(\hat{\beta})$ & $0.203^{* * *}$ & $0.158^{* *}$ & $0.178^{* *}$ & $0.136^{*}$ & $0.126^{*}$ \\
Matrilineal & $0.111^{* *}$ & $0.058^{*}$ & $0.076^{* *}$ & 0.080 & 0.069 \\
$\left(\hat{\beta}+\hat{\beta}_{M}\right)$ & & & & 338 & 338 \\
$N$ & 338 & 338 & 337 & 0.146 & 0.148 \\
$R^{2}$ & 0.143 & 0.137 & 0.140 & & 338 \\
\hline
\end{tabular}

*** Denotes significance at $1 \%$ level, ${ }^{* *}$ at $5 \%$ level and *at $10 \%$ level. For the sum of two coefficients, significance corresponds to an F-test on the joint significance of all coefficients

between domestic labor and leisure increases by a highly significant $30 \mathrm{~min}$ per day. The sum of the differences in regression (IV) is not significant, confirming a substitution effect. There is no effect of spending on economic labor. These results are consistent with those of the previous section and thus lend further support to the framework in Section 3.

\subsubsection{Heterogeneous responses and district-specific shocks}

In this section, I look for heterogeneous responses to changes in women's labor. In particular, there may be differential responses based on the characteristics of the household, such as poverty, land holdings and number of children. In specification (a) in Table 6, I interact the change in domestic labor with the change in the household's landholdings and add this to regression (1). Compared to the coefficient in regression (1) in Table 3, the significance of the coefficient on patriliny strengthens and the magnitude of the coefficient increases. Thus, the results are robust to a heterogeneous response by landholdings. The coefficient on the change in land size interacted with change in domestic labor is positive (result not shown); this suggests that where consumption outcomes and land holdings both increase, wives spend even more time on domestic labor. If an increase in land holdings captures an increase in household wealth, then this is consistent with the moral hazard framework of Section 3. In specification (b), I include the change in the poverty status of the household interacted with the change in domestic labor. Again, the results do not change. In specification (c), the change in the number of children in the household is interacted with the change in domestic labor, once again producing no change in the coefficients on patrilineal and matrilineal domestic labor responses. Thus, the results of the previous section are robust to accounting for heterogeneous responses by changes in characteristics such as land, poverty and number of children.

Another concern regarding the estimates in the previous section may be that there are district-specific shocks to labor. Recalling that the households are sampled from three different districts in Malawi (out of a total of 28 possible districts), I include district indicator variables in regression (d) in Table 6. These allow average changes in labor supply to vary across districts. The result shows that the magnitude of the coefficient on patriliny does not change in a significant way, although it becomes 
slightly less significant. Building on this, I also include district indicator variables interacted with the matrilineal indicator variable. This allows for any district-descentspecific shocks to labor. This is specification (e), where again there is no significant difference to the coefficient on patriliny. Thus, the results are robust to allowing for district-specific and district-descent-specific shocks to labor.

\subsubsection{Attitudes to divorce}

An examination of attitudes to divorce can help substantiate some of the assumptions that drive the interpretation of the results. In particular, a key assumption of the identification strategy is that matrilineal women are more able to divorce than patrilineal women. This is the reason why the former do not need to rely on withinmarriage sources of power as much as the latter. By examining attitudes to divorce in the face of husbands who do not provide financial support for their families, evidence for this assumption can be provided. In particular, husbands and wives were asked whether it is acceptable for a woman to divorce her husband if he does not provide for her or her children financially. In the Online Appendix, I provide the mean values of responses by lineage, marital residence and land inheritance. I describe the findings here. Overall, $53 \%$ of matrilineal women feel that they are able to divorce men who do not provide, which is significantly higher than the figure of $17 \%$ for patrilineal women. Divorce is also most acceptable among matrilineal-matrilocal women $(57 \%)$ and least acceptable for patrilineal-patrilocal women (16\%). A similar pattern is found when examining land inheritance: divorce is most acceptable for matrilineal women with inheritance $(59 \%)$. These observations are consistent with the regression results, where the strongest responses of domestic labor to consumption were observed for women with the lowest outside options.

An implicit assumption of the framework is that husbands cannot force their wives to behave in a certain way: they cannot use violence, for example. One way of testing this is to examine attitudes to violence in marriage. Respondents were asked whether it is acceptable for a woman to leave her husband if he beats her often. Most women report that they think it is acceptable to leave their husbands if they are violent, and there are no significant differences across kinship types. I find that $87 \%$ of matrilineal women and $83 \%$ of patrilineal women feel able to leave their husbands if they are violent. Therefore, it is unlikely that men can counteract the use of domestic production as an incentive device with violence.

\section{Conclusion}

This paper has explored whether domestic labor is used by wives as an incentive device in marriage. A moral hazard model of marriage in Malawi was derived, where the husband provides a rivalrous consumption good and the wife provides a public good. In addition, the wife may divorce the husband following a bad level of the consumption good. The existence of divorce threat acts as an additional source of incentives to encourage the husband to invest high effort. The model yielded the key prediction that wives with high outside options use less stringent domestic labor 
incentives than wives with low outside options. This led to the hypothesis that in Malawi, patrilineal wives increase their domestic labor more in response to increases in their clothes spending than matrilineal wives.

By examining the effect of wives' clothes and shoes spending on their domestic time use in a first-difference estimation strategy, the Proposition of the model have found strong support. Patrilineal wives increase their domestic labor by $10 \mathrm{~min}$ per day when they receive an additional $1000 \mathrm{MWK}$ of clothes spending. This effect is stronger than the effect for matrilineal wives. Patrilineal wives who are also patrilocal exhibit an even stronger effect, with the strongest effect for patrilineal wives with no land inheritance $(12 \mathrm{~min})$. The robustness of the results is confirmed by regressions on other time use variables, which show a clear substitution between leisure and domestic labor for wives with low outside options and no effect of changes in consumption on economic labor. I also verify that the results are robust to heterogeneous responses and district- and district-descent-specific shocks to labor. Through questions on attitudes to divorce, the key assumption that divorce is more accessible to women in matrilineal communities is supported. In addition, attitudinal responses show that most women would leave a violent husband, which suggests that women are freely able to manipulate their domestic labor.

The results imply that when divorce is not accessible, women rely on domestic labor as leverage within marriage. On the other hand, when divorce is accessible, this leverage device is less needed. Since using domestic labor as leverage results in an inefficient allocation of time, the accessibility of divorce should be encouraged in policy. One way of achieving this in developing countries is to grant women land rights, which give them financial security following divorce.

Acknowledgement I would like to thank the Editors and three anonymous referees, as well as Hamish Low, Pramila Krishnan, Wiji Arulampalam, Sylvie Lambert, Christine Valente, Ansgar Walther and participants in the applied microeconomics workshop at the University of Cambridge for helpful comments.

\section{Compliance with ethical standards}

Conflict of interest The authors declare that they have no conflict of interest. 


\section{Appendix A}

\section{Variables}

The following table gives details of the variables used in the regressions.

\begin{tabular}{|c|c|}
\hline Variable & Data \\
\hline Domestic & $\begin{array}{l}\text { Number of hours spent on cooking, cleaning and washing clothes during the previous } \\
\text { regular working day }\end{array}$ \\
\hline Leisure & $\begin{array}{l}\text { Number of hours spent on sleeping, community and village work, political meetings, } \\
\text { religious activities and other leisure activities during the previous regular working day }\end{array}$ \\
\hline Economic & $\begin{array}{l}\text { Number of hours spent on field preparation, ridging, planting, transplanting, fertilizing, } \\
\text { weeding, harvesting, animal care, gathering vegetables and other operations, wage } \\
\text { labor, group field labor, salaried employment, sales, handicraft and alcohol production, } \\
\text { transporting goods, metal work, basket weaving, carpentry, charcoal preparation, water } \\
\text { collection for sale and other cash activities. during the previous regular working day }\end{array}$ \\
\hline Other & $\begin{array}{l}\text { Number of hours spent on school attendance, eating, childcare, visiting friends, } \\
\text { collecting water and firewood, repairing the house and farm, attending funerals, caring } \\
\text { for the ill ( } 2006 \text { only) and sex ( } 2006 \text { only) during the previous regular working day }\end{array}$ \\
\hline Clothes & $\begin{array}{l}\text { Amount of money spent on wife's clothes, fabric for clothes or shoes in the past } 3 \\
\text { months }\end{array}$ \\
\hline Clothes_villmean & The mean of the variable Clothes in the village \\
\hline Land & The total amount of land the household owns, in acres \\
\hline Husbclothes & $\begin{array}{l}\text { Amount of money spent on husband's clothes, fabric for clothes or shoes in the past } 3 \\
\text { months }\end{array}$ \\
\hline
\end{tabular}

Open Access This article is distributed under the terms of the Creative Commons Attribution 4.0 International License (http://creativecommons.org/licenses/by/4.0/), which permits unrestricted use, distribution, and reproduction in any medium, provided you give appropriate credit to the original author(s) and the source, provide a link to the Creative Commons license, and indicate if changes were made.

\section{References}

Alfano, M., Arulampalam, W., \& Kambhampati, U. (2011). Maternal autonomy and the education of the subsequent generation: evidence from three contrasting states in India. IZA Discussion Paper Series 6019.

Anderson, S., \& Eswaran, M. (2009). What determines female autonomy? evidence from Bangladesh. Journal of Development Economics, 90, 179-191.

Aura, S. (2002). Uncommitted couples: some efficiency and policy implications of marital bargaining. CESifo Working Paper Series 810.

Becker, G. S. (1973). A theory of marriage: part I. Journal of Political Economy, 81(4), 813-846.

Becker, G. S. (1974). A theory of marriage: part II. Journal of Political Economy, 82(2), S11-S26.

Bignami-Van Assche, S., Van Assche, A., Anglewicz, P., Fleming, P., \& van de Ruit, C. (2011). HIV/ AIDS and time allocation in rural Malawi. Demographic Research, 24(27), 671-708.

Chiappori, P. -A. (1988). Rational household labor supply. Econometrica, 56(1), 63-89.

Cohen, L. (1987). Marriage, divorce and quasi rents; or, "i gave him the best years of my life". The Journal of Legal Studies, 16(2), 267-303. 
Cohen, R. (1971). Dominance and defiance: a study of marital instability in an Islamic African Society. Washington, D.C.: American Anthropological Association.

Denning, G., Kabambe, P., Sanchez, P., Malik, A., Flor, R., Harawa R., et al. (2009) Input subsidies to improve smallholder maize productivity in malawi: Toward an African green revolution. PLoS Biol, 7(1).

Ellis, F., Kutengule, M., \& Nyasulu, A. (2003). Livelihoods and rural poverty reduction in Malawi. World Development, 31(9), 1495-1510.

Engberg, L. E., Sabry, J. H., \& Beckerson, S. A. (1987). Production activities, food supply and nutritional status in Malawi. Journal of Modern African Studies, 25(1), 139-147.

England, P., \& Folbre, N. (2002). Involving dads: parental bargaining and family well-being. In: C. S. Tamis-LeMonda, \& N. Cabrera (Eds.), Handbook of father involvement: multidisciplinary perspectives (pp. 387-408). New Jersey: Lawrence Erlbaum Associates.

Friedberg, L., \& Stern, S. (2014). Marriage, divorce and asymmetric information. International Economic Review, 55(4), 1155--1199.

Green, E. J., \& Porter, R. H. (1984). Noncooperative collusion under imperfect price information. Econometrica, 52(1), 87-100.

Grossbard, A. (1976). An economic analysis of polygyny: the case of Maiduguri. Current Anthropology, 17(4), 701-707.

Grossbard-Schechtman, S., \& Lemennicier, B. (1999). Marriage contracts and the law-and-economics of marriage: an Austrian perspective. Journal of Socio-Economics, 28, 665-690.

Hart, O., \& Moore, J. (2008). Contracts as reference points. Quarterly Journal of Economics, 123(1), 1-48.

Hirschmann, D., \& Vaughan, M. (1983). Food production and income generation in a matrilineal society: rural women in Zomba, Malawi. Journal of Southern African Studies, 10(1), 86-99.

Kerr, R. B. (2005a). Food security in Northern Malawi: gender, kinship relations and entitlements in historical context. Journal of Southern African Studies, 31(1), 53-74.

Kerr, R. B. (2005b). Informal labor and social relations in Northern Malawi: the theoretical challenges and implications of ganyu labor for food security. Rural Sociology, 70(2), 167-187.

Kreps, D. M., \& Wilson, R. (1982). Reputation and imperfect information. Journal of Economic Theory, 27, 253-279.

Lamphere, L. (1974). Strategies, cooperation and conflict among women in domestic groups. In: M. Z. Rosaldo, \& L. Lamphere (Eds.), Woman, culture and society (pp. 97-112). Stanford, California: Stanford University Press.

Landes, E. M. (1978). Economics of alimony. The Journal of Legal Studies, 7(1), 35-63.

Lundberg, S., \& Pollak, R. A. (1993). Separate spheres bargaining and the marriage market. Journal of Political Economy, 101(6), 988-1010.

Lundberg, S., \& Pollak, R. A. (2001). Efficiency in marriage. National Bureau of Economic Research Working Paper Series 8642.

Manser, M., \& Brown, M. (1980). Marriage and household decision-making: a bargaining analysis. International Economic Review, 21(1), 31-44.

Peters, E. H. (1986). Marriage and divorce: informational constraints and private contracting. American Economic Review, 76(3), 437-454.

Peters, P. E. (1997). Against the odds. matriliny, land and gender in the shire highlands of Malawi. Critique of Anthropology, 17, 189-210.

Phiri, K. M. (1983). Some changes in the matrilineal family system among the chewa of Malawi since the nineteenth century. Journal of African History, 24, 257-274.

Phiri, K. M. (1985). Production and exchange in pre-colonial Malawi. Malawi: an alternative pattern of development. Centre for African Studies, University of Edinburgh, Seminar Proceedings no. 25: pp. $3-32$.

Pollak, R. A. (2005). Bargaining power in marriage: earnings, wage rates and household production. National Bureau of Economic Research Working Paper Series 11239.

Rasul, I. (2008). Household bargaining over fertility: theory and evidence from Malaysia. Journal of Development Economics, 86, 215-241.

Reniers, G. (2003). Divorce and remarriage in rural Malawi. Demographic Research Special Collection, 1(6), 175-206.

Safilios-Rothschild, C. (1982). Female power, autonomy and demographic change in the third world. In: R. Anker, M. Buvinic, \& N. H. Youssef (Eds.), Women's roles and population trends in the third world. International Labour Organisation (pp. 117-133). London: Croom Helm Ltd.

Souza, P. Z. (2013). Moral Hazard in the Family. Mimeo.https://docs.google.com/file/d/0B8opvNgZBbUd3lvTkR5R2RtUU0/edit 
Spring, A. (1995). Agricultural development and gender issues in Malawi. Maryland: University Press of America, Inc.

Takane, T. (2008). Labour use in smallholder agriculture in Malawi: six village case studies. African Study Monographs, 29(4), 183-200.

Udry, C. (1996). Gender, agricultural production and the theory of the household. The Journal of Political Economy, 104(5), 1010-1046.

Walther, S. (2016). Kinship and consumption: The effect of descent on household productivity. University of Oxford, Department of Economics, Discussion Paper 720. Mimeo. 